\title{
ANALISIS TERHADAP SYARAT PENGUNDURAN DIRI DARI KEDUDUKAN/JABATAN TERTENTU BAGI CALON KEPALA DAERAH
}

\author{
Oleh \\ Rajin Sitepu \\ rajinsitepu331@gmail.com \\ Fakultas Syariah dan Hukum UIN Sumatera Utara
}

\begin{abstract}
This article discusses the issues on the requirements of resignation from certain positions for Regional Head Candidates. This article answers the questions: in which regional election regulations these requirements were first determined, what are the relevance to other laws, what is the basis for these requirements, and how are the implications of these requirements for the implementation of the regional elections (pilkada). After going through an analytical and critical thinking process of the regional government regulations/ regional election regulation that have been in effect, it was found that the requirements were first determined in Law Number 22 of 2014 on the Election of Governors, Regents and Mayors. Legislation relating to this law are the ASN Law, the TNI Law, the Law of the National Police of the Republic of Indonesia, and the Constitutional Court Decree Number 41 / PUU-XII / 2014 and Number 33 / PUU-XIII / 2015. The background to this requirement is the fact that after the 1998 reform, there was already a ban on civil servants from becoming members of political parties and the abolishment of ABRI's dual function (TNI / Polri). Due to the prohibition of civil servants and the elimination of the dual function, there are no more civil servants and members of the ABRI who sit in representative institutions (DPR and $M P R$ ) authorized to determine the law. The implication of these requirements for the implementation of the regional elections is to limit members of the DPR, DPD and DPRD, the members of the TNI / Polri, $P N S$ and Village Heads and any positions in BUMN and BUMD to run for regional heads. These restriction has narrowed the choice of candidates in the implementation of the regional elections. It is recommended that the regional election be broadly followed by Regional Head Candidates, and by each group and background so that it can produce the truly best, strong and qualified Regional Head.In addition, the resignation should be carried out when the Regional Head Candidate has actually been elected and appointed as Regional Head.
\end{abstract}

Keywords: the regional elections, candidate requirements, the regional Head Candidate 


\section{A. Latar Belakang}

Sepanjang sejarah pemerintahan, beberapa peraturan perundangan tentang pemerintahan daerah telah pernah berlaku. Mulai dari yang pertama kali berlaku Undang-Undang Nomor 1 Tahun 1945, hingga yang terakhir dan masih berlaku hingga saat sekarang ini Undang-Undang Nomor 9 Tahun 2015. Undang-undang ini pun sudah dua kali mengalami perubahan, terakhir dengan Undang-Undang Nomor 10 Tahun $2016 .{ }^{1}$

Sebagai suatu peraturan perundangan tentang pemerintahan daerah, tentu banyak hal yang diatur di dalamnya. Segala hal atau seluk-beluk yang menyangkut pemerintahan daerah diatur dalam peraturan perundangan tersebut. Mulai dari kewenangan daerah, penataan daerah, penyelenggaraan pemerintahan daerah, sampai kepala daerah diatur dalam peraturan perundangan tersebut.

Dari sekian banyak hal yang diatur dalam peraturan perundangan tersebut, tulisan ini bermaksud untuk menganalisis salah satu hal saja dari seluk-beluk pemerintahan daerah. Hal tersebut adalah masalah Kepala Daerah. Bagaimanakah pengisian jabatan dan syarat calon Kepala Daerah diatur dalam peraturan perundangan yang pernah berlaku, akan coba diungkapkan dalam tulisan ini.

Melihat peraturan perundangan yang pernah berlaku, menunjukkan bahwa ketentuan tentang sistem pengisian jabatan dan syarat calon Kepala Daerah terus mengalami perubahan atau pembaharuan dari satu peraturan perundangan ke peraturan perundangan lainnya. Di antara pembaharuan syarat calon Kepala Daerah itu, pembaharuan yang terakhir adalah yang terdapat dalam UndangUndang Nomor 9 Tahun 2015 yang telah dua kali dirubah, terakhir dengan Undang-Undang Nomor 10 Tahun 2016 tentang Perubahan Kedua atas Undang-Undang Nomor 1 Tahun 2015 tentang Pemilihan Gubernur, Bupati, dan Walikota menjadi Undang-Undang (selanjutnya disebut Undang-Undang Pilkada).

Di dalam Pasal 7 ayat (2) Undang-Undang Pilkada ditentukan Calon Gubernur dan Calon Wakil Gubernur, Calon Bupati dan Calon Wakil Bupati, serta Calon Walikota dan Calon Wakil Walikota antara lain harus memenuhi persyaratan sebagai berikut:

1. Menyatakan secara tertulis pengunduran diri sebagai anggota Dewan Perwakilan Rakyat (DPR), anggota Dewan Perwakilan Daerah (DPD), dan anggota Dewan Perwakilan Rakyat Daerah (DPRD) sejak ditetapkan sebagai pasangan calon peserta pemilihan (berlaku bagi calon Kepala

${ }^{1}$ Undang-undang Nomor 9 Tahun 2015 yang telah dua kali mengalami perubahan, terakhir dengan Undang-Undang Nomor 10 Tahun 2016 ini adalah undang-undang yang secara khusus mengatur tentang pemilihan gubernur, bupati, dan walikota. Sebelum peraturan ini ada, pengaturan tentang pengisian jabatan Kepala Daerah diatur dalam peraturan perundangan tentang pemerintahan daerah. Diaturnya secara khusus pemilihan Kepala Daerah dalam undang-undang tersendiri baru dimulai sejak tahun 2015 dengan diundangkannya Undang-Undang Nomor 9 Tahun 2015. 
Daerah yang berkedudukan sebagai anggota DPR, DPD, dan anggota DPRD);

2. Menyatakan secara tertulis pengunduran diri sebagai anggota Tentara Nasional Indonesia (TNI), Kepolisian Negara Republik Indonesia (Polri), dan Pegawai Negeri Sipil (PNS) serta Kepala Desa atau sebutan lain sejak ditetapkan sebagai pasangan calon peserta pemilihan (berlaku bagi calon Kepala Daerah yang berkedudukan sebagai anggota TNI, Polri, PNS, serta Kepala Desa);

3. Berhenti dari jabatan pada Badan Usaha Milik Negara (BUMN) atau Badan Usaha Milik Daerah (BUMD) sejak ditetapkan sebagai calon (berlaku bagi calon Kepala Daerah yang berkedudukan pada BUMN atau BUMD).

Lebih lanjut terkait dengan persyaratan keharusan mengundurkan diri ini, dalam Pasal 4 ayat (1) Peraturan Komisi Pemilihan Umum Nomor 1 Tahun 2020 tentang Perubahan Ketiga Atas Peraturan Komisi Pemilihan Umum Nomor 3 Tahun 2017 tentang Pencalonan Pemilihan Gubernur dan Wakil Gubernur, Bupati dan Wakil Bupati, dan/atau Walikota dan Wakil Walikota (lebih lanjut disebut dengan PKPU tentang Pencalonan) ditentukan sebagai berikut:

1. Bagi calon Kepala Daerah yang berkedudukan sebagai anggota DPR, DPD, dan anggota DPRD, menyatakan secara tertulis pengunduran diri sebagai anggota DPR, DPD, atau DPRD sejak ditetapkan sebagai calon;

2. Bagi calon Kepala Daerah yang berkedudukan sebagai anggota TNI, Polri, PNS serta Kepala Desa, menyatakan secara tertulis pengunduran diri sebagai anggota TNI, Polri, PNS, serta Kepala Desa atau sebutan lain sejak ditetapkan sebagai calon;

3. Bagi calon Kepala Daerah yang berkedudukan pada BUMN atau BUMD, berhenti dari jabatan pada BUMN atau BUMD yang tidak dapat ditarik kembali sejak ditetapkan sebagai calon.

Syarat keharusan mengundurkan diri dari kedudukan atau jabatan-jabatan tertentu sebagaimana ditentukan dalam Undang-Undang Pilkada yang lebih lanjut ditentukan pula dalam PKPU tentang Pencalonan tersebut menarik perhatian Penulis untuk membahasnya. Dalam peraturan perundangan pemerintahan daerah/pemilihan kepala daerah yang manakah pertama kali persyaratan tersebut ditentukan, termasuk relevansinya dengan peraturan perundangan lainnya, apakah yang melatarbelakangi dan yang membuat persyaratan itu ada, serta apakah implikasinya terhadap pelaksanaan pilkada, kesemuanya itu akan dibahas berikut ini.

\section{B. Sistem Pengisian Jabatan dan Syarat Calon Kepala Daerah dalam Peraturan Perundangan yang Pernah Berlaku}

Dari sejarah penyelenggaraan pemilihan Kepala Daerah, kita ketahui bahwa kita pernah memakai paling tidak tiga macam sistem pemilihan Kepala Daerah. Sistem yang pertama adalah sistem pengangkatan, sistem yang kedua adalah sistem pemilihan secara tidak langsung, dan sistem yang ketiga adalah sistem pemilihan secara langsung. 
Sistem pengangkatan adalah sistem pengisian jabatan Kepala Daerah yang dilakukan melalui pengangkatan, tidak melalui pemilihan. Pengisian jabatan Kepala Daerah melalui sistem ini berlangsung dalam kurun waktu yang cukup panjang dalam sejarah pemerintahan daerah. Pertama di bawah Undang-Undang Nomor 1 Tahun 1945, pengisian jabatan Kepala Daerah ketika itu dilakukan dengan sistem pengangkatan. Begitupun di bawah Undang-Undang Nomor 22 Tahun 1948 tentang Pemerintahan di Daerah.

Di dalam Pasal 18 Undang-Undang Nomor 22 Tahun 1948 ditentukan bahwa Kepala Daerah Provinsi (Gubernur) diangkat oleh Presiden dari calon yang diajukan oleh Dewan Perwakilan Rakyat Daerah Provinsi, Kepala Daerah Kabupaten diangkat oleh Menteri Dalam Negeri dari calon yang diajukan oleh Dewan Perwakilan Rakyat Daerah Kabupaten.

Memang dalam Undang-Undang Nomor 1 Tahun 1957 sempat ada ketentuan mengenai pemilihan Kepala Daerah secara langsung oleh rakyat, namun secara empirik pemilihan secara langsung oleh rakyat tersebut belum dapat dilaksanakan. ${ }^{2}$

Setelah Undang-Undang Nomor 1 Tahun 1957, berdasarkan Penetapan Presiden Nomor 6 Tahun 1959 dan dengan Undang-Undang Nomor 18 Tahun 1965, pengisian jabatan Kepala Daerah kembali ditentukan berdasarkan pengangkatan. Dalam Penetapan Presiden dan dalam Undang-Undang ini ditentukan Kepala Daerah diangkat dan diberhentikan oleh Presiden atau Menteri Dalam Negeri melalui calon yang diajukan oleh DPRD.

Pada masa pemerintahan Orde Baru, dengan Undang-Undang Nomor 5 Tahun 1974 tentang Pokok-Pokok Pemerintahan di Daerah, sistem pengisian jabatan Kepala Daerah kembali ditentukan dengan sistem pengangkatan. Kepala Dearah diangkat oleh Presiden dari calon yang memenuhi syarat setelah melalui seleksi calon yang dilakukan oleh DPRD. Namun Kepala Daerah bukan hasil pemilihan dari DPRD, karena jumlah dukungan suara dalam pencalonan tidak menghalangi Presiden untuk mengangkat siapa saja di antara para calon itu. Dalam beberapa kasus, Kepala Daerah yang dipilih bukanlah pilihan nomor 1 yang diusulkan DPRD. Pada tahun 1985, kandidat nomor 1 Gubernur Riau Ismail Suko dikalahkan oleh Imam Munandar yang merupakan kandidat nomor 2. Pada pemilihan Bupati Sukabumi, calon nomor 2 Ragam Santika juga akhirnya diangkat sebagai Bupati. ${ }^{3}$

Selanjutnya sistem pengisian jabatan Kepala Daerah berikutnya adalah sistem pemilihan secara tidak langsung. Sistem pemilihan secara tidak langsung adalah sistem pengisian jabatan Kepala Daerah yang dilakukan oleh wakil rakyat di DPRD, tidak dilakukan secara langsung oleh rakyat.

Dalam sejarah penyelenggaraan pemilihan Kepala Daerah, sistem pemilihan secara tidak langsung ini terjadi di bawah Undang-Undang Nomor 22 Tahun 1999. Kepala Daerah pada saat itu dipilih oleh anggota DPRD. Berbeda dengan di masa sebelumnya di mana DPRD hanya mengusulkan nama-nama Calon Kepala Daerah dan kemudian Kepala Daerah tersebut

${ }^{2}$ Joko J. Prihatmoko, Pemilihan Kepala Daerah Langsung, Filosofi, Sistem, dan Problema Penerapan di Indonesia, Pustaka Pelajar, Yogyakarta, 2005. Hal. 55.

${ }^{3}$ Ibid. Hal. 65 . 
dipilih oleh Presiden dari calon-calon tersebut, maka dalam sistem pemilihan secara tidak langsung, Kepala Daerah dipilih oleh anggota DPRD.

Akhirnya sistem pemilihan Kepala Daerah yang ketiga, yang berlaku sekarang ini adalah sistem pemilihan secara langsung. Sistem pemilihan secara langsung adalah sistem pengisian jabatan Kepala Daerah yang dilakukan melalui pemilihan umum Kepala Daerah, di mana rakyat selaku pemilih secara langsung memberikan suaranya untuk satu pasangan calon yang mereka inginkan agar pasangan calon tersebut dapat terpilih. Pemilihan Kepala Daerah secara langsung pertama kali dilaksanakan pada tanggal 1 Juni 2005. Pemilihan tersebut dilaksanakan berdasarkan Undang-Undang Nomor 32 Tahun 2004 tentang Otonomi Daerah. ${ }^{4}$

Demikianlah sistem pengisian jabatan Kepala Daerah yang pernah berlaku sepanjang sejarah penyelenggaraan pemerintahan daerah, selanjutnya akan diuraikan pula apa sajakah persyaratan menjadi Kepala Daerah dalam beberapa peraturan perundangan yang pernah berlaku. Persyaratan yang diuraikan berikut ini adalah dalam kaitannya dengan sistem pengisian jabatan Kepala Daerah sebagaimana telah diuraikan di atas, yakni sistem pengangkatan, sistem pemilihan secara tidak langsung, dan sistem pemilihan secara langsung.

\section{Undang-Undang Nomor 5 Tahun 1974 tentang Pokok-Pokok Pemerintahan di Daerah}

Di dalam Pasal 14 Undang-Undang ini ditentukan: Yang dapat diangkat menjadi Kepala Daerah ialah Warga Negara Indonesia yang memenuhi syaratsyarat sebagai berikut:

a. Takwa kepada Tuhan Yang Maha Esa;

b. Setia dan taat kepada Pancasila dan Undang-Undang Dasar 1945;

c. Setia dan taat kepada negara dan pemerintah;

d. Tidak pernah terlibat baik langsung maupun tidak langsung dalam setiap kegiatan yang menghianati Negara Kesatuan Republik Indonesia yang berdasarkan Pancasila dan Undang-Undang Dasar 1945, seperti gerakan G-30 S/PKI dan/atau organisasi terlarang lainnya;

e. Mempunyai rasa pengabdian terhadap nusa dan bangsa;

f. Mempunyai kepribadian dan kepemimpinan;

g. Berwibawa;

h. Jujur;

i. Cerdas, berkemampuan, dan terampil;

j. Adil;

k. Tidak dicabut hak pilihnya berdasarkan keputusan pengadilan yang mempunyai kekuatan pasti;

1. Sehat jasmani dan rohani;

m. Berumur sekurang-kurangnya 35 (tiga puluh lima) tahun bagi Kepala Daerah Tingkat I dan 30 (tiga puluh) tahun bagi Kepala Daerah Tingkat II;

${ }^{4}$ Lebih jauh tentang sejarah penyelenggaraan pemilihan kepala daerah ini dapat dibaca pula dalam Bungasan Hutapea, Dinamika Pemilihan Kepala daerah di Indonesia, Jurnal Rechtsvinding, Volume 4 Nomor 1, April 2015. 
n. Mempunyai kecakapan dan pengalaman pekerjaan yang cukup di bidang pemerintahan;

o. Berpengetahuan yang sederajat dengan perguruan tinggi atau sekurangkurangnya berpendidikan yang dapat dipersamakan dengan sarjana muda bagi Kepala Daerah Tingkat I dan berpengetahuan sederajat dengan akademi atau sekurang-kurangnya berpendidikan yang dapat dipersamakan dengan sekolah lanjutan atas bagi Kepala daerah Tingkat II.

Persyaratan menjadi Kepala Daerah yang ditentukan dalam undangundang ini adalah persyaratan saat berlangsungnya sistem pengisian jabatan Kepala Daerah melalui cara pengangkatan yang berlangsung pada masa Pemerintahan Orde Baru hingga memasuki masa-masa awal Pemerintahan Orde Reformasi tahun 1998.

\section{Undang-Undang Nomor 22 Tahun 1999 tentang Pemerintahan Daerah}

Dalam Pasal 33 Undang-Undang ini ditentukan: Yang dapat diangkat menjadi Kepala Daerah adalah Warga Negara Republik Indonesia dengan syaratsyarat:

a. Bertakwa kepada Tuhan Yang Maha Esa;

b. Setia dan taat kepada Negara Kesatuan Republik Indonesia dan Pemerintah yang sah;

c. Tidak pernah terlibat dalam kegiatan yang menghianati Negara Kesatuan Republik Indonesia yang berdasarkan Pancasila dan Undang-Undang Dasar 1945 yang dinyatakan dengan surat keterangan ketua pengadilan negeri;

d. Berpendidikan sekurang-kurangnya Sekolah Lanjutan Tingkat Atas dan/atau sederajat;

e. Berumur sekurang-kurangnya tiga puluh tahun;

f. Sehat jasmani dan rohani;

g. Nyata-nyata tidak terganggu jiwa/ingatannya;

h. Tidak pernah dihukum penjara karena melakukan tindak pidana;

i. Tidak sedang dicabut hak pilihnya berdasarkan putusan pengadilan negeri;

j. Mengenal daerahnya dan dikenal oleh masyarakat di daerahnya;

k. Menyerahkan daftar kekayaan pribadi; dan

1. Bersedia dicalonkan menjadi Kepala Daerah.

Persyaratan menjadi Kepala Daerah yang ditentukan dalam undang-undang ini adalah persyaratan saat berlangsungnya sistem pengisian jabatan Kepala Daerah melalui pemilihan secara tidak langsung yang berlangsung di masa-masa awal Pemerintahan Orde Reformasi.

\section{Undang-Undang Nomor 32 Tahun 2004 dan Peraturan Pemerintah Nomor 6 Tahun 2005}

Dalam Pasal 58 Undang-Undang Nomor 32 dan Pasal 38 Peraturan Pemerintah Nomor 6 Tahun 2005 tentang Pemilihan, Pengesahan, Pengangkatan dan Pemberhentian Kepala Daerah dan Wakil Kepala Daerah ditentukan Calon Kepala Daerah dan Wakil Kepala Daerah adalah Warga Negara Republik Indonesia yang memenuhi syarat: 
a. Bertakwa kepada Tuhan Yang Maha Esa;

b. Setia kepada Pancasila sebagai dasar negara, Undang-Undang Dasar Negara Republik Indonesia Tahun 1945, cita-cita proklamasi 17 Agustus 1945, dan kepada Negara Kesatuan Republik Indonesia serta Pemerintah;

c. Berpendidikan sekurang-kurangnya sekolah lanjutan tingkat atas dan/atau sederajat;

d. Berusia sekurang-kurangnya 30 (tiga puluh) tahun;

e. Sehat jasmani dan rohani berdasarkan hasil pemeriksaan kesehatan menyeluruh dari tim dokter;

f. Tidak pernah dijatuhi pidana penjara berdasarkan putusan pengadilan yang telah memperoleh kekuatan hukum tetap karena melakukan tindak pidana yang diancam dengan pidana penjara paling lama 5 (lima) tahun atau lebih;

g. Tidak sedang dicabut hak pilihnya berdasarkan putusan pengadilan yang telah memperoleh kekuatan hukum tetap;

h. Mengenal daerahnya dan dikenal oleh masyarakat di daerahnya;

i. Menyerahkan daftar kekayaan pribadi dan bersedia untuk diumumkan;

j. Tidak sedang memiliki tanggungan utang secara perseorangan dan/atau secara badan hukum yang menjadi tanggung jawabnya yang merugikan keuangan negara;

k. Tidak sedang dinyatakan pailit berdasarkan putusan pengadilan yang telah memperoleh kekuatan hukum tetap;

1. Tidak pernah melakukan perbuatan tercela;

m. Memiliki Nomor Pokok Wajib Pajak (NPWP) atau bagi yang belum mempunyai NPWP wajib mempunyai bukti pembayaran pajak;

$\mathrm{n}$. Menyerahkan daftar riwayat hidup lengkap yang memuat antara lain riwayat pendidikan dan pekerjaan serta keluarga kandung, suami atau isteri;

o. Belum pernah menjabat sebagai Kepala Daerah atau Wakil Kepala Daerah selama 2 (dua) kali masa jabatan dalam jabatan yang sama; dan

p. Tidak dalam status sebagai Pejabat Kepala Daerah.

4. Undang-Undang Nomor 12 Tahun 2008 tentang Perubahan Kedua atas Undang-Undang Nomor 32 Tahun 2004 tentang Pemerintahan Daerah

Syarat Calon Kepala Daerah dalam Pasal 58 Undang-Undang Nomor 32 Tahun 2004 setelah diubah dengan Undang-Undang Nomor 12 Tahun 2008 sehingga berbunyi: Calon Kepala Daerah dan Wakil Kepala Daerah adalah Warga Negara Republik Indonesia yang memenuhi syarat:

a. Bertakwa kepada Tuhan Yang Maha Esa;

b. Setia kepada Pancasila sebagai dasar negara, Undang-Undang Dasar Negara Republik Indonesia Tahun 1945, cita-cita proklamasi 17 Agustus 1945, dan kepada Negara Kesatuan Republik Indonesia serta Pemerintah;

c. Berpendidikan sekurang-kurangnya Sekolah Lanjutan Tingkat Atas dan/atau sederajat;

d. Berusia sekurang-kurangnya 30 (tiga puluh) tahun bagi Calon Gubernur/Wakil Gubernur dan berusia sekurang-kurangnya 25 (dua puluh lima) tahun bagi Calon Bupati/Wakil Bupati dan Walikota/Wakil Walikota; 
e. Sehat jasmani dan rohani berdasarkan hasil pemeriksaan kesehatan menyeluruh dari tim dokter;

f. Tidak pernah dijatuhi pidana penjara berdasarkan putusan pengadilan yang telah memperoleh kekuatan hukum tetap karena melakukan tindak pidana yang diancam dengan pidana penjara 5 (lima) tahun atau lebih;

g. Tidak sedang dicabut hak pilihnya berdasarkan putusan pengadilan yang telah memperoleh kekuatan hukum tetap;

h. Mengenal daerahnya dan dikenal oleh masyarakat di daerahnya;

i. Menyerahkan daftar kekayaan pribadi dan bersedia untuk diumumkan;

j. Tidak sedang memiliki tanggungan utang secara perseorangan dan/atau secara badan hukum yang menjadi tanggung jawabnya yang merugikan keuangan negara;

k. Tidak sedang dinyatakan pailit berdasarkan putusan pengadilan yang telah memperoleh kekuatan hukum tetap;

1. Tidak pernah melakukan perbuatan tercela;

m. Memiliki Nomor Pokok Wajib Pajak (NPWP) atau bagi yang belum mempunyai NPWP wajib mempunyai bukti pembayaran pajak;

n. Menyerahkan daftar riwayat hidup lengkap yang memuat antara lain riwayat pendidikan dan pekerjaan serta keluarga kandung, suami atau isteri;

o. Belum pernah menjabat sebagai Kepala Daerah atau Wakil Kepala Daerah selama 2 (dua) kali masa jabatan dalam jabatan yang sama; dan

p. Tidak dalam status sebagai Penjabat Kepala Daerah.

q. Mengundurkan diri sejak pendaftaran bagi Kepala Daerah dan/atau Wakil Kepala Daerah yang masih menduduki jabatannya.

\section{Undang-Undang Nomor 22 Tahun 2014 tentang Pemilihan Gubernur, Bupati, dan Walikota}

Dalam Pasal 13 ayat (1) Undang-Undang ini ditentukan: Warga Negara Republik Indonesia yang dapat ditetapkan menjadi calon gubernur, calon bupati, dan calon walikota adalah yang memenuhi persyaratan sebagai berikut:

a. Bertakwa kepada Tuhan Yang Maha Esa;

b. Setia kepada Pancasila sebagai dasar negara, Undang-Undang Dasar Negara Republik Indonesia Tahun 1945, cita-cita Proklamasi Kemerdekaan 17 Agustus 1945, dan kepada Negara Kesatuan Republik Indonesia;

c. Berpendidikan paling rendah Sekolah Lanjutan Tingkat Atas atau sederajat;

d. Telah mengikuti uji publik;

e. Berusia paling rendah 30 (tiga puluh) tahun untuk calon gubernur dan 25 (dua puluh lima) tahun untuk calon bupati dan calon walikota;

f. Mampu secara jasmani dan rohani berdasarkan hasil pemeriksaan kesehatan menyeluruh dari tim dokter;

g. Tidak pernah dijatuhi pidana penjara berdasarkan putusan pengadilan yang telah mempunyai kekuatan hukum tetap karena melakukan tindak pidana yang diancam dengan pidana penjara di atas 5 (lima) tahun;

h. Tidak sedang dicabut hak pilihnya berdasarkan putusan pengadilan yang telah memperoleh kekuatan hukum tetap; 
i. Tidak pernah melakukan perbuatan tercela;

j. Menyerahkan daftar kekayaan pribadi;

k. Tidak sedang memiliki tanggungan utang secara perseorangan dan/atau secara badan hukum yang menjadi tanggung jawabnya yang merugikan keuangan negara;

1. Tidak sedang dinyatakan pailit berdasarkan putusan pengadilan yang telah memperoleh kekuatan hukum tetap;

m. Memiliki Nomor Pokok Wajib Pajak (NPWP) dan memiliki laporan pajak pribadi;

n. Belum pernah menjabat sebagai gubernur, bupati dan/atau walikota selama 2 (dua) kali masa jabatan dalam jabatan yang sama;

o. Berhenti dari jabatannya bagi gubernur, bupati dan walikota yang mencalonkan diri di daerah lain;

p. Tidak berstatus sebagai penjabat gubernur, penjabat bupati, dan penjabat walikota;

q. Tidak memiliki konflik kepentingan dengan petahana;

r. Memberitahukan pencalonannya sebagai gubernur, bupati dan walikota kepada pimpinan DPR, DPD, atau DPRD bagi angggota DPR, DPD, atau DPRD;

s. Mengundurkan diri sebagai anggota TNI/Polri dan PNS sejak mendaftarkan diri sebagai calon;

t. Berhenti dari jabatan pada Badan Usaha Milik Negara atau Badan Usaha Milik Daerah; dan

u. Tidak berstatus sebagai anggota panlih gubernur, bupati, dan walikota.

6. Undang-Undang Nomor 1 Tahun 2015 tentang Penetapan Peraturan Pemerintah Pengganti Undang-Undang Nomor 1 Tahun 2014 tentang Pemilihan Gubernur, Bupati, dan Walikota menjadi Undang-Undang, yang telah dua kali diubah, terakhir dengan Undang-Undang Nomor 10 Tahun 2016

Dalam Pasal 7 ayat (2) Undang-Undang ini ditentukan: Calon Gubernur dan Calon Wakil Gubernur, Calon Bupati dan Calon Wakil Bupati, serta Calon Walikota dan Calon Wakil Walikota harus memenuhi persyaratan sebagai berikut: a. Bertakwa kepada Tuhan Yang Maha Esa;

b. Setia kepada Pancasila, Undang-Undang Dasar Negara Republik Indonesia Tahun 1945, cita-cita Proklamasi Kemerdekaan 17 Agustus 1945, dan Negara

Kesatuan Republik Indonesia;

c. Berpendidikan paling rendah Sekolah Lanjutan Tingkat Atas atau sederajat;

d. Dihapus;

e. Berusia paling rendah 30 (tiga puluh) tahun untuk Calon Gubernur dan Calon Wakil Gubernur serta 25 (dua puluh lima) tahun untuk Calon Bupati dan Calon Wakil Bupati serta Calon Walikota dan Calon Wakil Walikota;

f. Mampu secara jasmani, rohani, dan bebas dari penyalahgunaan narkotika berdasarkan hasil pemeriksaan kesehatan menyeluruh dari tim;

g. Tidak pernah sebagai terpidana berdasarkan putusan pengadilan yang telah memperoleh kekuatan hukum tetap atau bagi mantan terpidana telah secara 
terbuka dan jujur mengemukakan kepada publik bahwa yang bersangkutan mantan terpidana;

h. Tidak sedang dicabut hak pilihnya berdasarkan putusan pengadilan yang telah mempunyai kekuatan hukum tetap;

i. Tidak pernah melakukan perbuatan tercela yang dibuktikan dengan surat keterangan catatan kepolisian;

j. Menyerahkan daftar kekayaan pribadi;

$\mathrm{k}$. Tidang sedang memiliki tanggungan utang secara perseorangan dan/atau secara badan hukum yang menjadi tanggung jawabnya yang merugikan keuangan negara;

1. Tidak sedang dinyatakan pailit berdasarkan putusan pengadilan yang telah mempunyai kekuatan hukum tetap;

m. Memiliki Nomor Pokok Wajib Pajak dan memiliki laporan pajak pribadi;

n. Belum pernah menjabat sebagai Gubernur, Wakil Gubernur, Bupati, Wakil Bupati, Walikota, dan Wakil Walikota selama 2 (dua) kali masa jabatan dalam jabatan yang sama untuk Calon Gubernur, Calon Wakil Gubernur, Calon Bupati, Calon Wakil Bupati, Calon Walikota, dan Calon Wakil Walikota;

o. Belum pernah menjabat sebagai Gubernur untuk Calon Wakil Gubernur, atau Bupati/Walikota untuk Calon Wakil Bupati/Calon Wakil Walikota pada daerah yang sama;

p. Berhenti dari jabatannya bagi Gubernur, Wakil Gubernur, Bupati, Wakil Bupati, Walikota, dan Wakil Walikota yang mencalonkan diri di daerah lain sejak ditetapkan sebagai calon;

q. Tidak berstatus sebagai penjabat Gubernur, Penjabat Bupati, dan penjabat Walikota;

r. Dihapus;

s. Menyatakan secara tertulis pengunduran diri sebagai anggota Dewan Perwakilan Rakyat, anggota Dewan Perwakilan Daerah dan Dewan Perwakilan Rakyat Daerah sejak ditetapkan sebagai pasangan calon peserta pemilihan;

t. Menyatakan secara tertulis pengunduran diri sebagai anggota Tentara Nasional Indonesia, Kepolisian Negara Republik Indonesia, dan Pegawai Negeri Sipil serta Kepala Desa atau sebutan lain sejak ditetapkan sebagai pasangan calon peserta pemilihan; dan

u. Berhenti dari jabatan pada Badan Usaha Milik Negara atau Badan Usaha Milik Daerah sejak ditetapkan sebagai calon.

Persyaratan menjadi Kepala Daerah yang ditentukan mulai dari UndangUndang Nomor 32 Tahun 2004 hingga Undang-Undang Nomor 22 Tahun 2014 yang telah dua kali dirubah, terakhir dengan Undang-Undang Nomor 10 Tahun 2016 ini adalah persyaratan saat berlangsungnya sistem pengisian jabatan Kepala Daerah melalui pemilihan secara langsung yang berlangsung pada masa Pemerintahan Orde Reformasi sekarang ini.

\section{Ketentuan mengenai Syarat Pengunduran Diri dari Jabatan tertentu bagi Calon Kepala Daerah dalam Peraturan Perundangan}


Sebagaimana telah disebutkan pada bagian Latar Belakang, bahwa persyaratan mengundurkan diri dari jabatan/kedudukan tertentu bagi Calon Kepala Daerah itu ditentukan dalam Pasal 7 ayat (2) Undang-Undang Pilkada; dan lebih lanjut ditentukan dalam Pasal 4 ayat (1) PKPU tentang Pencalonan.

Apabila diruntut ke belakang, persyaratan pengunduran diri ini sebenarnya bukan sesuatu yang baru, persyaratan ini pertama kali ditentukan dalam UndangUndang Nomor 22 Tahun 2014 tentang Pemilihan Gubernur, Bupati, dan Walikota.

Selain ketentuan tersebut, berikut ini adalah peraturan perundangan yang relevan dengan persyaratan pengunduran diri sebagai berikut:

1. Undang-Undang Nomor 5 Tahun 2014 tentang Aparatur Sipil Negara (selanjutnya disingkat Undang-Undang ASN)

Ada 2 pasal dalam Undang-Undang ASN yang terkait dengan ketententuan pengunduran diri PNS, yakni:

a. Pasal 119 yang menentukan: "Pejabat pimpinan tinggi madya dan pejabat pimpinan tinggi pratama yang akan mencalonkan diri menjadi gubernur dan wakil gubernur, bupati/walikota dan wakil bupati/wakil walikota wajib menyatakan pengunduran diri secara tertulis dari PNS sejak mendaftar sebagai calon." dan

b. Pasal 123 ayat (3) yang menentukan: "Pegawai ASN dari PNS yang mencalonkan diri atau dicalonkan menjadi Presiden dan Wakil Presiden, Ketua, Wakil Ketua, dan Anggota Dewan Perwakilan Rakyat, Ketua, Wakil Ketua, dan Anggota Dewan Perwakilan Daerah, Gubernur dan Wakil Gubernur, Bupati/Walikota dan Wakil Bupati/Wakil Walikota wajib menyatakan pengunduran diri secara tertulis sebagai PNS sejak mendaftar sebagai calon.

Berdasarkan putusan Mahkamah Konstitusi Nomor 41/PUUXII/2014, pengunduran diri yang dimaksud dalam Pasal 119 dan 123 ayat (3) Undang-Undang ASN dilakukan bukan pada saat mendaftar, melainkan pada saat ditetapkan secara resmi sebagai calon oleh penyelenggara pemilihan. Begitu pula dengan pengunduran diri yang dimaksud dalam Pasal 13 ayat (1) Undang-Undang Nomor 22 Tahun 2014, Pasca putusan Mahkamah Konstitusi ini, yakni dalam Pasal 7 ayat (2) Undang-Undang Nomor 1 Tahun 2015 ditetapkan bukan pada saat mendaftar, melainkan sejak ditetapkan sebagai pasangan calon peserta pemilihan.

2. Undang-Undang Nomor 34 Tahun 2004 tentang Tentara Nasional Indonesia (TNI)

Dalam Pasal 47 Undang-Undang ini ditentukan: "Prajurit hanya dapat menduduki jabatan sipil setelah mengundurkan diri atau pensiun dari dinas aktif keprajuritan."

3. Undang-Undang Nomor 2 Tahun 2002 tentang Kepolisian Negara Republik Indonesia

Dalam Pasal 28 ayat (3) Undang-Undang ini ditentukan: "Anggota Kepolisian Negara Republik Indonesia dapat menduduki jabatan di luar kepolisian setelah mengundurkan diri atau pensiun dari dinas kepolisian." 
4. Putusan Mahkamah Konstitusi Nomor 33/PUU-XIII/2015 yang menyatakan anggota DPR, DPD, dan DPRD harus mengajukan pengunduran diri secara tertulis sejak ditetapkan menjadi peserta pemilihan Kepala Daerah.

Terkait dengan pengunduran diri ini, Hasyim Asyari, Komisioner KPU mengatakan terdapat 3 dokumen yang harus diserahkan oleh peserta pilkada dari TNI/Polri, PNS, dan Legislatif, yakni:

a. Surat Pernyataan Bersedia Mengundurkan diri dari Jabatannya, diserahkan pada saat masa pendaftaran;

b. Surat Keterangan dari Lembaga/Instansi yang berisi tentang pengunduran diri sedang dalam proses, diserahkan pada $\mathrm{H}+5$ setelah penetapan calon; dan

c. Surat Keputusan (SK) Pengunduran Diri, diserahkan H+60 setelah penetapan calon. ${ }^{5}$

\section{Latar Belakang Adanya Persyaratan Pengunduran Diri dari Kedudukan/Jabatan Tertentu bagi Calon Kepala Daerah}

Melihat peraturan perundangan pemerintahan daerah/pemilihan kepala daerah yang pernah berlaku, persyaratan pengunduran diri dari kedudukan/jabatan tertentu ini pertama kali ditentukan dalam UndangUndang Nomor 22 Tahun 2014 tentang Pemilihan Gubernur, Bupati, dan Walikota. Sebelumnya persyaratan ini belum pernah ditentukan dalam peraturan perundangan pemerintahan daerah/pemilihan kepala daerah. Sudah barang tentu terdapat hal-hal dan kondisi-kondisi serta situasi politik tertentu yang melatarbelakangi dan memungkinkan hal tersebut terjadi, apa sajakah hal-hal itu, akan dianalisis berikut ini.

Sebagaimana diketahui, bahwa sejak jatuhnya pemerintahan Orde Baru yang otoriter dan sentralistis pada tahun 1998, pemerintahan memasuki babak baru yang dikenal dengan pemerintahan Reformasi yang lebih demokratis dan desentralistis. Sejak saat itu telah terjadi reformasi di berbagai bidang kehidupan berbangsa dan bernegara, baik reformasi di bidang politik, militer, birokrasi pemerintahan maupun reformasi di bidang-bidang kehidupan berbangsa dan bernegara lainnya. Di antara sejumlah agenda reformasi tersebut, agenda reformasi berikut ini menurut Penulis berkorelasi dan menjadi sebab musabab hingga adanya ketentuan tentang persyaratan pengunduran diri dari kedudukan/jabatan tertentu bagi Calon Kepala Daerah dalam peraturan perundangan pemerintahan daerah/pemilihan kepala daerah.

Menurut Penulis adanya persyaratan pengunduran diri dari kedudukan/jabatan tertentu bagi Calon Kepala Daerah tersebut adalah diawali dan tidak terlepas dari agenda reformasi di bidang birokrasi kepegawaian yang terjadi di tahun 1999. Dengan ditetapkannya Peraturan Pemerintah Nomor 5 Tahun 1999 tentang Pegawai Negeri Sipil Yang Menjadi Anggota Partai Politik, yang intinya melarang Pegawai Negeri Sipil (PNS) menjadi anggota partai politik, merupakan awal dan cikal bakal dari adanya 
persyaratan pengunduran diri PNS dalam peraturan perundangan pemerintahan daerah/pemilihan kepala daerah. Praktis sejak saat itu tidak lagi ada PNS yang menjadi anggota partai politik dan mengisi keanggotaan lembaga perwakilan rakyat (DPR dan MPR) yang menyuarakan dan memperjuangkan aspirasi dan kepentingan-kepentingan politik PNS.

Menurut Penulis apabila tidak ada larangan bagi PNS untuk menjadi anggota partai politik, dan PNS masih mengisi keanggotaan lembaga perwakilan, mungkin saja persyaratan pengunduran diri dari PNS itu tidak pernah ada, karena mereka tentu akan berjuang di lembaga perwakilan untuk mempertahankan kepentingan-kepentingan mereka.

Begitu juga halnya dengan persyaratan pengunduran diri dari anggota TNI/Polri, menurut Penulis hal itu juga tentu sama halnya dengan reformasi di bidang birokrasi kepegawaian, diawali dan tidak terlepas dari agenda reformasi di bidang militer. Penghapusan dwifugsi TNI (ketika itu ABRI) menjadikan anggota TNI/Polri tidak lagi terlibat dalam dunia politik, dan mengisi serta membentuk fraksi di lembaga perwakilan. Apabila mereka masih terlibat dalam dunia politik dan mengisi keanggotaan lembaga perwakilan, mungkin sama halnya dengan PNS, persyaratan pengunduran diri dari anggota TNI/Polri dalam peraturan perundangan yang sekarang ini mungkin tidak pernah ada.

Begitulah agenda reformasi, baik di tubuh birokrasi kepegawaian dan di tubuh TNI/Polri telah membawa perubahan dan warna baru di lembaga perwakilan. Sejak saat itu lembaga perwakilan tidak lagi diisi oleh kehadiran PNS dan TNI/Polri yang berikutnya memunculkan adanya persyaratan pengunduran diri dari anggota TNI/Polri dan PNS dalam peraturan perundangan pemilihan kepala daerah.

Menurut Penulis seharusnya lembaga perwakilan sebagai pembentuk undang-undang lebih bijak melihat persoalan ini. Jangan oleh karena dorongan nafsu dan syahwat politik untuk berkuasa (keinginan menjadi Kepala Daerah), dipersempit dan diperkecil persaingan dan kompetisi untuk menjadi Kepala Daerah dengan membatasi PNS dan TNI/Polri untuk mencalonkan diri menjadi Kepala Daerah.

Para legislator di lembaga perwakilan seharusnya mendahulukan kepentingan yang lebih besar yakni kepentingan bangsa dan negara, bukan kepentingan golongan dan partai politik. Kepentingan bangsa dan negara menghendaki melalui pilkada dapat dilahirkan Kepala Daerah yang benarbenar terbaik, yang kuat dan mumpuni, oleh karenanya tidak seharusnya dilakukan pembatasan-pembatasan bagi setiap orang, setiap golongan, dan setiap latar belakang, termasuk anggota DPR, DPD, DPRD dan anggota TNI/Polri, PNS dan Kepala Desa serta dari kalangan BUMN dan BUMD untuk mendaftarkan diri menjadi Calon Kepala Daerah.

\section{E. Implikasi dari Persyaratan Pengunduran Diri dari Kedudukan/Jabatan Tertentu terhadap Pelaksanaan Pilkada}

Apakah yang menjadi implikasi dari adanya persyaratan pengunduran diri tersebut terhadap pelaksaan pilkada, jawabannya tentu mudah 
dibayangkan, persyaratan tersebut telah memperkecil dan mempersempit pilihan Calon Kepala Daerah dalam pelaksaan pilkada. Persyaratan pengunduran diri tersebut telah membatasi anggota DPR, DPD, dan DPRD, begitu pula PNS, anggota TNI/Polri dan Kepala Desa serta dari jabatan pada BUMN dan BUMD untuk mendaftarkan diri sebagai Calon Kepala Daerah sebab mereka sudah harus mengundurkan diri padahal belum tentu terpilih dan ditetapkan sebagai Kepala Daerah. ${ }^{6}$

Pilkada yang hanya diikuti oleh calon yang kecil dan terbatas menurut Penulis tidak baik dan tidak mendukung untuk terpilihnya Kepala Daerah yang terbaik, kuat dan mumpuni. Kepala Daerah yang terbaik, kuat dan mumpuni akan lahir melalui pilkada yang diikuti oleh Calon Kepala Daerah secara luas, dari setiap golongan dan setiap latar belakang tanpa ada pembatasan-pembatasan, termasuk dari anggota DPR, DPD dan DPRD serta PNS, anggota TNI/Polri dan Kepala Desa serta jabatan pada BUMN dan BUMD.

Pengunduran diri dari anggota DPR, DPD, dan DPRD serta anggota TNI/Polri, PNS dan Kepala Desa serta dari jabatan pada BUMN dan BUMD setelah ditetapkan menjadi peserta pilkada dijadikan alasan untuk menjamin netralitas anggota TNI/Polri, PNS dan Kepala Desa dalam pelaksanaan pilkada, menurut hemat Penulis kurang beralasan. Disebut kurang beralasan karena untuk menjamin netralitas anggota TNI/Polri, PNS dan Kepala Desa dalam pelaksanaan pilkada telah ada aturannya sendiri, jadi bukan dengan cara menetapkan mereka harus mundur setelah ditetapkan menjadi peserta pilkada. ${ }^{7}$

Masalah netralitas anggota TNI/Polri, PNS, dan Kepala Desa diatur dalam Pasal 71 ayat (1) juncto Pasal 188 Undang-Undang Pilkada sebagai berikut: Pasal 71 ayat (1) menentukan: "Pejabat negara, pejabat daerah, pejabat aparatur sipil negara, anggota TNI/Polri, dan kepala desa atau sebutan lain/lurah dilarang membuat keputusan dan/atau tindakan yang menguntungkan atau merugikan salah satu pasangan calon." Pasal 188 menentukan: "Setiap pejabat negara, pejabat aparatur sipil negara, dan kepala desa atau sebutan lain/lurah yang dengan sengaja melanggar ketentuan sebagaimana dimaksud dalam Pasal 71 , dipidana dengan pidana penjara paling singkat 1 (satu) bulan atau paling lama 6 (enam) bulan dan/atau denda

${ }^{6}$ Pangi Syarwi Chaniago, Evaluasi Pilkada Pelaksanaan Pilkada Serentak Tahun 2015, dalam journal Politik Indonesia: Indonesia Political Science Review 1 (2), Universitas Islam Negeri Syarif Hidayatullah, Indonesia, 2016 dalam salah satu kesimpulannya menyatakan untuk meminimalisir munculnya calon tunggal sebaiknya kembali pada aturan main sebelumnya yakni pasangan calon bagi PNS, TNI/Polri, anggota DPR, DPD, dan DPRD wajib mundur sejak ditetapkan sebagai pemenang kepala daerah/wakil kepala daerah terpilih, bukan saat penetapan pasangan pencalonan.

${ }^{7}$ Menyangkut masalah persyaratan pengunduran diri ini dalam kaitannya dengan hak konstitusional, khususnya hak Pegawai Negeri Sipil dalam pemilihan kepala daerah, lihat Inong, Hak Konstitusional Pegawai Negeri Sipil (PNS) dalam Pencalonan sebagai Kepala Daerah, eJurnal Katalogis, Volume 3 Nomor 11, November 2015, h. 162-172. 
paling sedikit $\mathrm{Rp} 600.000,00$ (enam ratus ribu rupiah) atau paling banyak $\mathrm{Rp}$ 6.000.000,00 (enam juta rupiah)." 8

Menurut Penulis agar pelaksanaan pilkada itu diikuti oleh Calon Kepala Daerah secara luas, oleh setiap golongan dan setiap latar belakang, biarlah pengunduran diri sebagai anggota DPR, DPD dan DPRD, anggota TNI/Polri, PNS dan Kepala Desa serta dari jabatan pada BUMN dan BUMD itu dipersyaratkan setelah benar-benar terpilih dan ditetapkan menjadi Kepala Daerah.

Dengan ditetapkan pengunduran diri itu setelah benar-benar terpilih dan ditetapkan menjadi Kepala Daerah, menjadikan tidak lagi ada keengganan bagi anggota DPR, DPD, DPRD dan anggota TNI/Polri, PNS dan Kepala Desa serta dari jabatan pada BUMN dan BUMD untuk mendaftarkan diri menjadi Calon Kepala Daerah. Dengan demikian pilkada akan dapat diikuti oleh Calon Kepala Daerah secara luas, dari setiap golongan dan setiap latar belakang, termasuk oleh anggota DPR, DPD, dan DPRD serta anggota TNI/Polri, PNS dan Kepala Desa serta dari jabatan pada BUMN dan BUMD. Pilkada yang diikuti oleh calon secara luas akan menghasilkan/melahirkan Kepala Daerah yang benar-benar terbaik, kuat dan mumpuni.

Yang terpenting dalam pelaksanaan pilkada ini, Kepala Daerah yang berasal dari anggota DPR, DPD dan DPRD serta anggota TNI/Polri, PNS dan Kepala Desa serta dari jabatan pada BUMN dan BUMD itu tidak rangkap jabatan, begitu terpilih dan ditetapkan menjadi Kepala Daerah, mengundurkan diri dari kedudukan/jabatannya sebagai anggota DPR, DPD dan DPRD serta anggota TNI/Polri, PNS dan Kepala Desa serta dari jabatan pada BUMN dan BUMD.

\section{F. Kesimpulan} berikut:

Beberapa hal yang dapat disimpulkan dari tulisan ini adalah sebagai

1. Terdapat 3 macam sistem pengisian jabatan kepala daerah dalam peraturan perundangan Pemerintahan Daerah/Pemilihan Kepala Daerah yang pernah berlaku, yakni: pertama, Sistem pengangkatan; kedua, sistem pemilihan tidak langsung; dan ketiga, sistem pemilihan langsung.

2. Peraturan perundangan yang pertama kali mempersyaratkan pengunduran diri bagi anggota DPR, DPD, dan DPRD serta anggota TNI/Polri, PNS dan Kepala Desa serta dari jabatan pada BUMN dan BUMD yang mencalonkan diri menjadi kepala daerah adalah Undang-Undang Nomor 22 Tahun 2014 tentang Pemilihan Gubernur, Bupati dan Walikota.

${ }^{8}$ Menurut Penulis terdapat ketidaksingkronan di antara Pasal 71 ayat (1) dan Pasal 188 Undang-Undang Pilkada ini. Dalam Pasal 71 yang dilarang membuat keputusan dan/atau tindakan yang menguntungkan atau merugikan salah satu pasangan calon itu adalah pejabat negara, pejabat daerah, pejabat aparatur sipil negara, anggota TNI/Polri, dan kepala desa atau sebutan lain/lurah, sementara yang dipidana dalam Pasal 188 apabila melanggar ketentuan Pasal 71 ayat (1) hanya pejabat negara, pejabat aparatur sipil negara, dan kepala desa atau sebutan lain/lurah, tidak termasuk anggota TNI/Polri. Ketidaksingkronan tersebut terjadi adalah karena Pasal 71 sudah diubah, sementara perubahan tersebut tidak disertai dengan perubahan Pasal 188. 
Adapun peraturan perundangan yang terkait dengan persyaratan pengunduran diri tersebut adalah Undang-Undang ASN, Undang-Undang TNI, Undang-Undang Kepolisian Negara Republik Indonesia, dan Keputusan Mahkamah Konstitusi Nomor 41/PUU-XII/2014 dan Nomor 33/PUU-XIII/2015.

3. Latar belakang hingga dapat ditetapkannya persyaratan pengunduran diri dari anggota DPR, DPD dan DPRD serta anggota TNI/Polri, PNS dan Kepala Desa serta dari jabatan pada BUMN dan BUMD yang mencalonkan diri menjadi Kepala Daerah adalah karena pasca reformasi 1998 sudah ada larangan bagi PNS untuk menjadi anggota partai politik dan penghapusan dwifungsi ABRI. Larangan bagi PNS dan penghapusan dwifungsi tersebut menjadikan tidak lagi ada PNS dan ABRI yang duduk di lembaga perwakilan (DPR dan MPR) yang berwenang menetapkan undang-undang.

4. Implikasi dari persyaratan pengunduran diri dari anggota DPR, DPD dan DPRD serta anggota TNI/Polri, PNS dan Kepala Desa serta dari jabatan pada BUMN dan BUMD yang mencalonkan diri menjadi kepala daerah adalah persyaratan tersebut telah membatasi anggota DPR, DPD dan DPRD serta anggota TNI/Polri, PNS dan Kepala Desa serta dari jabatan pada BUMN dan BUMD untuk mencalonkan diri menjadi Kepala Daerah. Pembatasan tersebut telah memperkecil dan mempersempit pilihan calon dalam pelaksanaan pilkada.

\section{G. Rekomendasi}

Disarankan pengunduran diri dari anggota DPR, DPD dan DPRD serta anggota TNI/Polri, PNS dan Kepala Desa serta dari jabatan pada BUMN dan BUMD yang mencalonkan diri menjadi Kepala Daerah adalah setelah benarbenar terpilih dan ditetapkan menjadi Kepala Daerah, bukan setelah ditetapkan menjadi peserta dalam pilkada seperti yang ditentukan dalam peraturan perundangan sekarang ini. Disarankannya hal ini adalah agar tidak lagi ada keengganan bagi anggota DPR, DPD dan DPRD serta anggota TNI/Polri, PNS dan Kepala Desa serta dari jabatan pada BUMN dan BUMD untuk mencalonkan diri sebagai Calon Kepala Daerah. Turut sertanya anggota DPR, DPD dan DPRD serta anggota TNI/Polri, PNS dan Kepala Desa serta dari jabatan pada BUMN dan BUMD dalam pelaksaan pilkada akan dapat memperluas pilihan calon, sehingga pilkada dapat menghasilkan/kepala daerah yang benar-benar terbaik, kuat dan mumpuni.

\section{Daftar Pustaka}

Hutapea, Bungasan. Dinamika Pemilihan Kepala daerah di Indonesia, Jurnal Rechtsvinding, Volume 4 Nomor 1, April 2015.

Andayani, Dwi. DetikNews, Senin, 08 Januari 2018. 
Inong, Hak Konstitusional Pegawai Negeri Sipil (PNS) dalam Pencalonan Sebagai Kepala Daerah, e-Jurnal Katalogis, Volume 3 Nomor 11, November 2015.

Prihatmoko, Joko J. Pemilihan Kepala Daerah Langsung, Filosofi, Sistem, dan Problema Penerapan di Indonesia, Pustaka Pelajar, Yogyakarta, 2005.

Pangi Syarwi Chaniago, Evaluasi Pilkada Pelaksanaan Pilkada Serentak Tahun 2015, journal Politik Indonesia: Indonesia Political Science Review 1 (2), Universitas Islam Negeri Syarif Hidayatullah, Indonesia, 2016.

Undang-Undang Nomor 5 Tahun 1974 tentang Pokok-Pokok Pemerintahan di Daerah

Undang-Undang Nomor 22 Tahun 1999 tentang Pemerintahan Daerah

Undang-Undang Nomor 32 Tahun 2004 dan Peraturan Pemerintah Nomor 6 Tahun 2005

Undang-Undang Nomor 12 Tahun 2008 tentang Perubahan Kedua atas Undang-Undang Nomor 32 Tahun 2004 tentang Pemerintahan Daerah

Undang-Undang Nomor 22 Tahun 2014 tentang Pemilihan Gubernur, Bupati, dan Walikota

Undang-Undang Nomor 1 Tahun 2015 tentang Penetapan Peraturan Pemerintah Pengganti Undang-Undang Nomor 1 Tahun 2014 tentang Pemilihan Gubernur, Bupati, dan Walikota menjadi Undang-Undang, yang telah dua kali diubah, terakhir dengan Undang-Undang Nomor 10 Tahun 2016

Undang-Undang Nomor 5 Tahun 2014 tentang Aparatur Sipil Negara (selanjutnya disingkat Undang-Undang ASN)

Undang-Undang Nomor 34 Tahun 2004 tentang Tentara Nasional Indonesia (TNI)

Undang-Undang Nomor 2 Tahun 2002 tentang Kepolisian Negara Republik Indonesia 